\title{
Secretion of Immunoglobulins and Plasma Proteins from the Jejunal Mucosa \\ Transport Rate and Origin of Polymeric Immunoglobulin A
}

P. P. Jonard, J. C. Rambaud, C. Dive, J. P. Vaerman, A. Galian, and D. L. Delacroix Department of Pathology, Hôpital Lariboisière, and Research Unit on Pathophysiology of Digestion (INSERM U-54), Hôpital Saint-Lazare, Paris, France; Unit of Experimental Medicine, International Institute of Cellular and Molecular Pathology, and Unit of Gastroenterology; Cliniques Universitaires St-Luc, Catholic University of Louvain, Brussels, Belgium

bstract. Parameters of secretion of IgA and several other plasma proteins from the jejunal mucosa were investigated in 11 individuals who had a normal distribution of Ig-containing cells in the lamina propria and in one patient who was totally deficient in jejunal IgA and IgM plasmacytes. Jejunal samples were collected during segmental gut perfusion. The following results were obtained: ( $a$ ) The secretion of polymeric $\operatorname{IgA}(\mathrm{p}-\operatorname{IgA}$, mean equals $217 \mu \mathrm{g} / 40 \mathrm{~cm}$ per min) exceeded those of albumin $(132 \mu \mathrm{g}), \operatorname{IgG}(35 \mu \mathrm{g})$, and monomeric IgA (m-IgA, 15 $\mu \mathrm{g}$, or $6.4 \%$ of total $\operatorname{IgA}$ ). About $35 \%$ of $\operatorname{IgA}$ was $\operatorname{IgA} 2$ in the jejunal secretion, compared with $\sim 23 \%$ in serum. This closely corresponds to the 35 and $24 \%$ of $\operatorname{IgA} 2$ plasmocytes in jejunal mucosa and peripheral lymph nodes, respectively. (b) For each protein, a relative coefficient of excretion (RCE) was calculated (jejunum to serum concentration ratio expressed relative to that of albumin). RCEs of 1.41 for orosomucoid, 1.0 for albumin, 0.83 for IgG, and 0.74 for IgE and, in the deficient patient, of 0.64 for $\mathrm{m}$-IgA and 0.016 for IgM were obtained. This was inversely related to the molecular weight of these proteins and indicated their predominantly passive transport into the jejunum. However, in normal individuals,

Dr. Jonard has received a grant from the Collège de Médecine des Hôpitaux de Paris, France. Dr. Delacroix is Chargé de Recherches at the Fonds National de la Recherche Scietifique, Brussels, Belgium. His present address for correspondence and reprints is Catholic University of Louvain, Gastroenterology Unit.

Received for publication 4 January 1984 and in revised form 23 April 1984.

J. Clin. Invest.

(C) The American Society for Clinical Investigation, Inc.

$0021-9738 / 84 / 08 / 0525 / 11 \$ 1.00$

Volume 74, August 1984, 525-535 the RCE of transferrin $(\sim 1.11>1, P>0.05), \alpha_{2}$-macro globulin $(\sim 0.77)$, m-IgA $(\sim 1.98)$, and p-IgA $(\sim 218)$ exceeded the value expected from simple seepage from plasma, thus pointing to an additional role of either local gut synthesis and/or active transepithelial transport. (c) Approximately $98 \%$ of $\mathrm{p}-\operatorname{IgA}, \sim 99 \%$ of $\operatorname{IgM}$, and $\sim 68 \%$ of $\mathrm{m}$-IgA in jejunal secretions were derived from local production in the gut wall, as determined by ${ }^{125} \mathrm{I}-\mathrm{p}$-IgA specific activities and/or by comparison between the RCE values of the deficient patient to the values of controls. Therefore, the jejunal production of p-IgA $(\sim 312 \mathrm{mg} / \mathrm{d}$ per $40 \mathrm{~cm}$ vs. $\sim 54 \mathrm{mg} / \mathrm{d}$ from bile) contributes the majority of upper intestinal IgA in humans. The active transport of plasma p-IgA across the intestinal mucosa $(\sim 0.08$ $\mathrm{mg} / 40 \mathrm{~cm}$ per $\mathrm{kg}$ per d) contributes $<2 \%$ of the total amount of p-IgA $(4.5 \mathrm{mg} / \mathrm{kg}$ per d) that is cleared daily from plasma.

\section{Introduction}

The parameters of secretion of Ig and plasma proteins from intestinal mucosa are still poorly characterized. Most plasma proteins are believed to reach the gut lumen as a result of passive leakage from lamina propria capillaries (1). In addition, other mechanisms such as local protein synthesis in the gut lamina propria and receptor-mediated active transepithelial transport also contribute to the secretion of some proteins. This is well documented for polymeric $\operatorname{IgA}(\mathrm{p}-\operatorname{Ig} A)^{\prime}$ and $\operatorname{IgM}(2-6)$. However,

1. Abbreviations used in this paper: Alb, albumin; d-IgA, dimeric IgA; FITC, fluorescein isothiocyanate; IRMA, immunoradiometric assay; $\alpha_{2} \mathrm{M}, \alpha_{2}$-macroglobulin; m-IgA, monomeric IgA; ORO, orosomucoid; PEG, polyethyleneglycol 4,000; p-IgA, polymeric IgA; RCEs, relative (to albumin) coefficient of excretion(s); SC, secretory component; SDGU, sucrose density gradient ultracentrifugation; TRITC, tetramethylrhodamine isothiocyanate. 
the respective contributions of plasma IgA vs. gut-synthesized IgA are still unknown.

The intestinal lamina propria is populated by a wealth of plasmocytes, of which $80 \%$ produce IgA and $15 \%$ produce IgM $(7,8)$. Over half of this IgA is in polymeric form (9-11), and $\sim 35 \%$ of it is $\operatorname{Ig} A 2(12)$. In contrast, plasma $\operatorname{IgA}$ is predominately monomeric $(\mathrm{m}-\operatorname{IgA})$, and of the $\operatorname{IgA} 1$ subclass $(5,13)$, and is mostly produced in the bone marrow $(11,14)$. Only p-IgA (and IgM), which is locally produced or comes from plasma (12\%) (13), has a high affinity for the secretory component (SC) (15, 16), which is a glycoprotein that acts on the basolateral membrane of epithelial cells as a transmembrane receptor for polymeric Ig (17-19). The SC initiates the active translocation of p-IgA and IgM across the epithelial cells from the lamina propria to the gut lumen $(3,4,19)$. So far, the transport of $p$-IgA from plasma into intestinal secretions has not been studied.

Therefore, this study analyzes the jejunal secretion rate of IgA and of other plasma proteins and pays particular attention to the different molecular sizes ( $\mathrm{m}$ - and $\mathrm{p}$-), subclasses (IgA1 and $\operatorname{IgA} 2$ ), and origins of $\operatorname{IgA}$. Pure jejunal secretions were collected by segmental perfusion of the gut, which thus avoided protein and proteolytic enzyme contamination. The transport rate of $\mathrm{p}$-IgA from plasma into the jejunum and the contribution of plasma $\mathrm{p}$-IgA to the total jejunal $\mathrm{p}$ - $\operatorname{IgA}$ were assessed radioisotopically. We also studied a patient who was totally deficient in IgA and IgM plasmacytes in the jejunal lamina propria. In this individual, it was assumed that all IgA and IgM present in the gut lumen was of plasma origin.

\section{Methods}

\section{Subjects}

12 subjects (eight caucasians and four blacks; ten males and two females) with a mean age of $40 \mathrm{yr}(28-52 \mathrm{yr})$ were included in the study. They comprised 11 controls with a normal gastrointestinal status and one patient who lacked IgA- and IgM-containing plasma cells in the jejunal lamina propria.

Controls. The control group included two healthy volunteers and nine patients who were referred to the Hospital Saint-Lazare because of cryptogenic abdominal complaints. After complete investigation, which included jejunal biopsy, none of these patients showed evidence of organic gastrointestinal or immunological abnormality. All these individuals were submitted to jejunal perfusion. Jejunal biopsy was obtained after perfusion under endoscopic control. Two of these patients were also injected intravenously with $5-10 \mu \mathrm{Ci}$ each of ${ }^{131} \mathrm{I}$-albumin and ${ }^{125} \mathrm{I}-\mathrm{p}$-IgA. Informed consent was obtained from all individuals, and the protocol of the study was approved by the Ethics Committee of the Hospital Saint-Lazare.

Patient lacking lamina propria IgA and IgM plasmacytes. This Chadian patient ( 33 yr old) had suffered from mild diarrhea for several years. Complete gastrointestinal investigations and immunofluorescence studies that were performed on three separate occasions revealed a complete absence of IgA- and IgM-containing cells in his jejunal lamina propria, which was associated with low serum levels of IgA and IgM. This patient was also submitted to jejunal perfusion after informed consent had been obtained. His jejunal biopsy sample revealed no evidence of villous atrophy or inflammation.

\section{Jejunal perfusion}

Segmental perfusion of the jejunum $(20,21)$ was performed according to Rambaud et al. (22), using a four-lumen tube. The tube was comprised of a proximal segment that had a lumen opening in the duodenum, an inflatable balloon that was able to occlude the duodeno-jejunal junction, a distal segment with an upper infusion point, and a distal collection point that was $40 \mathrm{~cm}$ below the infusion point. The tube was set in place $16 \mathrm{~h}$ before the perfusion. The infusion point was located near the duodeno-jejunal junction by using fluoroscopic control just before perfusion. The gut was perfused with a $115 \mathrm{mM} \mathrm{NaCl}, 10 \mathrm{mM} \mathrm{KCl}$, and $35 \mathrm{mM}$ mannitol solution that was supplemented with polyethyleneglycol 4,000 (PEG) $(\mathrm{lg} / \mathrm{l})$, at a rate of $10 \mathrm{ml} / \mathrm{min}$. In order to rinse the secretions that were present in the jejunal lumen, a 60 -min equilibration period was allowed after the inflation of the balloon with 50 $80 \mathrm{ml}$ of air. After the equilibration period, four 20 -min samples were collected by continuous free siphoning and kept at $4^{\circ} \mathrm{C} .1 \mathrm{mM}$ diisopropylfluorophosphate, a potent serine protease inhibitor, was added to each sample. A serum sample was obtained from each patient after the second 20-min period. Serum and perfusate samples were stored at $-20^{\circ} \mathrm{C}$.

During the perfusion, duodenal contents were continuously collected and discarded. Contamination of the jejunal samples by duodenal fluids bypassing the balloon was controlled by using two semiquantitative methods: detection of bromosulfophtalein, which was infused above the balloon into the duodenum, and detection of chymotrypsin or lipase activity in perfusates. Five 20-min samples from three patients were excluded after detection. Absence of blood contamination was confirmed in all samples (Hemotest, Ames, France).

Protein concentrations in serum and jejunal perfusate. In general, the protein concentrations in serum and jejunal samples were measured using the same methods, reagents, and standards as described by Delacroix et al. (23). Specific concentrations of albumin (Alb), transferrin, IgG, IgA, and IgM in serum were measured by immunonephelometry (24). IgA in the serum of the deficient patient, $\alpha_{2}$-macroglobulin $\left(\alpha_{2} \mathrm{M}\right)$, and orosomucoid (ORO) in all sera, and all proteins in jejunal samples, including SC, were measured by immunoradiometric assay (IRMA) (23, 25 ). Goat serum ( $\alpha_{2}$ M and IgM IRMA) or horse serum (all other IRMA) were added to jejunal samples in order to keep them in a protein-rich buffer.

These aliquots were assayed at four serial dilutions (minimal dilution was $1 / 12.5$ for $\alpha_{2} \mathrm{M}$ ). Results for the dilutions falling within the standard ranges $(4-100 \mathrm{ng} / \mathrm{ml})$ always yielded curves closely parallel to the standard curves. For the deficient patient, jejunal samples were concentrated 100 fold by vacuum ultrafiltration before protein measurements. For both immunonephelometry and IRMA, the same pool of normal serum $(1,000$ blood donors) was used as standard.

IgE was assayed in concentrated (20-80 times) intestinal fluids and in serum by particle counting immunoassay (26). Before the assay, intestinal samples were diluted with 1 vol of normal rabbit serum to minimize the effect of protein concentration in the agglutination process, and were digested with pepsin. In $30 \mathrm{~min}$, pepsin releases the $\mathrm{Fc}^{\prime \prime}$-fragment (D1-determinant) from IgE or its partially fragmented components, whereas already existing $\mathrm{Fc}^{\prime \prime}$-fragments are not further degraded to any major extent (27). The Fc"-fragment was then assayed by its agglutinating activity towards latex particles that were coated with anti-IgE-Fc" antibodies. Serum IgE was assayed in the same way after pepsin digestion of diluted serum. The degree of concentration of jejunal samples was always measured by comparing Alb and lgG levels in the concentrated and unconcentrated samples.

Ultracentrifugation and measurement of $m$ - and $p$-IgA. The proportions of $\mathrm{m}$ - and $\mathrm{p}$-IgA in all sera and perfusate samples were measured 
after sucrose density gradient ultracentrifugation (SDGU). Samples were centrifuged for $16 \mathrm{~h}$ at $38,000 \mathrm{rpm}\left(\omega^{2} t=9.11 \times 10^{11}\right)$ on isokinetic $(5-21 \%)$ sucrose gradients using the same $7 \mathrm{~S}$ and $10.5 \mathrm{~S}$ markers as previously described $(23,28)$. The amounts of serum $(4-6 \mu \mathrm{l})$ and secretion $(50-300 \mu \mathrm{l})$ applied to the gradients were based upon their respective IgA concentrations. For the deficient patient, $60 \mu \mathrm{l}$ of serum and $300 \mu \mathrm{l}$ of the 100 -fold concentrated (vacuum dialysis) perfusate were applied. IgA concentrations were measured (IRMA) in the 30 fractions of $0.4 \mathrm{ml}$ that were eluted from SDGU after dilution 1:9 in $20 \%$ horse serum. Percentages of $\mathrm{m}$ - and $\mathrm{p}$-IgA were measured by planimetry. Absolute concentrations of $\mathrm{m}$ - and $\mathrm{p}$-IgA were calculated from the total IgA levels multiplied by the percentages determined above. The influence of the size of IgA in IRMA (25), but not in nephelometry (29), was taken into account by multiplying all results obtained by IRMA by a factor of 2 for $\mathrm{p}$-IgA in secretions, or of 1.5 or 2 for dimeric and heavier IgA, respectively, in serum (23).

The proportions of free and bound SC in each perfusate sample, and the molecular size of other proteins in a 100-fold concentrated pool of perfusate samples from controls, were determined according to the same methods as for IgA. Appropriate IRMA and dilutions were used.

IgA subclasses in serum and perfusate. IgA1 and IgA2 (30-32) concentrations in serum and perfusate were measured by IRMA and performed as previously described (33), with modifications using monoclonal antibodies. Three mouse monoclonal antibodies, anti- $\alpha 1$, anti- $\alpha 2$ and anti- $\alpha$-chain, were obtained in our laboratory. ${ }^{2}$ Their specificity was verified by means of various highly sensitive immunoassays, using 10 human monoclonal IgA proteins of each subclass. In these preliminary experiments, ${ }^{2}$ we used both $\mathrm{m}(1)$ and $\mathrm{m}(2)$ allotypes of IgA2 (34), both isotypes of light chains, and both Fab and Fc fragments of IgAl. Antisubclass antibodies were used to coat the solid phase, and the purified anti- $\alpha$-chain antibody was labeled and used as second antibody. Standards $(5-150 \mathrm{ng} / \mathrm{ml})$ were made with a serum pool of 1,000 blood donors. The pool contained $21 \%$ IgA2 and $79 \%$ IgA1, as previously measured $(13,33)$. The influence of the size of IgA1 and IgA2 in these assays ${ }^{2}$ was also carefully assessed, using highly purified monomeric and dimeric monoclonal IgA1 and IgA2 as controls in all assays. Results were expressed as $(\operatorname{IgA} 2) /(\operatorname{IgA} 1+\operatorname{Ig} A 2) \times 100$. The sum of $(\operatorname{Ig} A 1+\operatorname{Ig} A 2)$ concentrations averaged $115 \pm 18 \%$ of total IgA concentration in serum and $94 \pm 20 \%$ in perfusate.

\section{Immunochemistry}

Jejunal biopsies were obtained in nine control patients and in the patient lacking jejunal IgA and IgM plasmocytes. To compare the IgA-subclass distribution in the jejunal lamina with that in the peripheral lymph nodes, three histologically normal lymph nodes were obtained from patients operated on for laryngeal and breast cancer.

Jejunal biopsies. In each case, five tissue samples were obtained using a forceps that was passed through an endoscope. They were fixed in Bouin's fluid, dehydrated, and embedded in paraffin within $12 \mathrm{~h}$. For each patient, a standard staining procedure allowed selection of the two best-oriented specimens. Serial 3- $\mu \mathrm{m}$ thick sections were then processed for immunohistochemistry.

Immunohistochemical procedures. Before applying antisera, all sections were incubated for $60 \mathrm{~min}$ with a 100 times dilution (in phosphatebuffered saline [PBS]) of a normal serum of the species corresponding to the conjugated antiserum used.

IgA-, IgM- (goat antisera used in IRMA), and IgG (fluorescein isothiocyanate [FITC] conjugated rabbit antiserum, Dako, Denmark)-containing cells were stained on serial sections using an indirect staining

2. Delacroix, D. L., et al., manuscript in preparation. procedure for IgA and IgM (FITC-conjugated rabbit antigoat IgG antiserum, Nordic, Netherlands) and a direct procedure for IgG. Each antiserum was applied for $60 \mathrm{~min}$ at room temperature. IgA 1- and IgA2containing cells were simultaneously stained on the same section using a double-tracing technique. Sections were simultaneously incubated with the mouse monoclonal anti-IgA2 antibody ${ }^{2}$ and with a rabbit anti-IgA1 antiserum (33) for $60 \mathrm{~min}$, washed in PBS for $30 \mathrm{~min}$, further incubated for $60 \mathrm{~min}$ with FITC anti-mouse and tetramethylrhodamine isothiocyanate (TRITC) anti-rabbit antisera (Nordic), then washed again for $30 \mathrm{~min}$.

Fluorescence was observed with a Wild-Leitz Ortholux II equipped with a Ploem-type vertical illuminator, and 4-20 objective fields $(\times 25)$ (mean equals six fields for IgA, IgA1, IgA2, and IgM and 15 for IgG) were micrographed on Kodak Ektachrome 200 daylight film (Eastman Kodak Co., Rochester, NY) (final 100 times magnification), using appropriate filters. In the double-tracing procedure, the same fields were successively micrographed for IgA1 (red) and IgA2 (green). Both red and green fluorescence were also simultaneously micrographed on the same section.

Controls. Controls included: specific inhibition experiments by antiserum absorption with appropriate antigens, absence of staining when the second labeled antisera were directly applied on sections, and absence of red staining when the TRITC-goat anti-rabbit antiserum was applied on sections that were incubated with mouse anti-IgA2 antibodies.

Morphometry. The micrographs were projected on a semiautomatic image analyzer (Nacher, NS 1000, Levallois-Peret, France) and the following parameters were recorded: surface of the analyzed mucosa, corresponding lamina propria surface, and the number of green- or redstained plasmocytes. The absolute and relative distributions of IgA, IgM, and $\mathrm{IgG}$, as well as those of IgA1 and IgA2 plasmocytes, were calculated.

\section{Radioisotopic studies}

${ }^{125} \mathrm{I}$-dimeric IgA and ${ }^{131} \mathrm{I}$-albumin were simultaneously injected intravenously into two control patients $16 \mathrm{~h}$ before jejunal perfusion. Specific radioactivities were simultaneously measured in serum and perfusate in order to determine the proportion of $\mathrm{p}$-IgA or of $\mathrm{Alb}$ in perfusate that was derived from plasma. Immunochemical and biological characteristics as well as the labeling procedure for the injected dimeric polyclonal IgA have been previously described in detail $(13,23,28)$. This Ig was essentially pure (28), was not complexed to SC (28), contained an appropriate amount of J-chain (13), was able to bind SC, and was transported at a high rate from plasma into bile of rats and rabbits $(23,35) .{ }^{131} \mathrm{I}$-albumin was purchased from Sorin Biomedica s.p.a. (Saluggia, Italia) and was homogeneous in size when submitted to SDGU. The following procedures were used to measure specific activities in serum and perfusate. Two samples of serum, obtained before and after the jejunal perfusion, were pooled. All 20-min perfusion samples were pooled after an aliquot of each had been frozen. The pools of perfusate ( 250 and $450 \mathrm{ml}$, respectively, in the two patients) were concentrated by vacuum ultrafiltration and adjusted to 3 $\mathrm{ml}$. Radioactivities in both serum $(3 \mathrm{ml})$ and concentrated perfusates $(3 \mathrm{ml})$ were counted for $20 \mathrm{~min}$ before and after precipitation with TCA at $100 \mathrm{~g} / \mathrm{l}$ final concentration. Concentrations of $\mathrm{p}-\mathrm{IgA}$ and $\mathrm{Alb}$ in serum and concentrated perfusate were measured according to standard procedures. In one of the two patients, the concentrated perfusate $(300 \mu \mathrm{l})$ was submitted to SDGU in order to compare the size profile of ${ }^{125}$ I-radioactivity to the profile of the cold IgA (IRMA) in the sample. Specific activity ratios were calculated from: (TCA precipitable counts/ $\mathrm{mg}$ of $\mathrm{p}$-IgA or $\mathrm{Alb} / 20 \mathrm{~min}$ ) in perfusate/(TCA precipitable counts/mg of $\mathrm{p}$-IgA or $\mathrm{Alb} / 20 \mathrm{~min}$ ) in serum.

Mathematical and statistical analysis. Net movements of water, electrolytes, and proteins in the jejunal test segments are listed in Table 
Table I. Transintestinal Water and Electrolyte Movements during Jejunal Perfusion

\begin{tabular}{|c|c|c|}
\hline & Mean* & Range \\
\hline Perfusion flow rate $\left(\mathrm{ml} \cdot \mathrm{min}^{-1}\right)$ & 10.08 & $9.20-11.43$ \\
\hline [PEG]p/[PEG]sł & 0.952 & $0.872-1.124$ \\
\hline Net water flux $\left(\mathrm{ml} \cdot \mathrm{min}^{-1} \cdot 40 \mathrm{~cm}^{-1}\right)$ & -0.48 & $-1.21-+1.28$ \\
\hline Net $\mathrm{Na}$ flux $\left(\mathrm{mmol} \cdot \mathrm{min}^{-1} \cdot 40 \mathrm{~cm}^{-1}\right)$ & -0.02 & $-0.10-+0.06$ \\
\hline Net $\mathrm{K}$ flux $\left(\mathrm{mmol} \cdot \mathrm{min}^{-1} \cdot 40 \mathrm{~cm}^{-1}\right)$ & -0.03 & $-0.05-+0.03$ \\
\hline Net $\mathrm{Cl}$ flux $\left(\mathrm{mmol} \cdot \mathrm{min}^{-1} \cdot 40 \mathrm{~cm}^{-1}\right)$ & -0.08 & $-0.17-+0.03$ \\
\hline \multicolumn{3}{|l|}{ Net bicarbonate flux } \\
\hline$\left(\mathrm{mmol} \cdot \mathrm{min}^{-1} \cdot 40 \mathrm{~cm}^{-1}\right)$ & +0.01 & $+0.01-0.02$ \\
\hline
\end{tabular}

* Arithmetic mean value $(n=12)$.

¥ Concentration of PEG at the perfusion point (p) and the sampling point (s), respectively.

I. They were calculated as follows: $(a)$ FRs $=$ FRp $\times($ PEG $)$ p/(PEG)s, where FRs and (PEG)s are the fluid flow rates and PEG concentration at the sampling point, whereas FRp and (PEG)p are fluid flow rate and PEG concentration at the perfusion point. (b) Net water flux $\left(\mathrm{ml} \cdot \mathrm{min}^{-1} \cdot 40 \mathrm{~cm}^{-1}\right)=$ FRp - FRs. (c) Net electrolyte flux $\left(\mathrm{mmol} \cdot \mathrm{min}^{-1} \cdot 40 \mathrm{~cm}^{-1}\right)=($ FRp $\times$ electrolyte $p)-($ FRs $\times$ electrolyte $s)$, where electrolyte $s$ and electrolyte $p$ are electrolyte concentrations at the sampling and perfusion points, respectively. $(d)$ Protein secretion rate $\left(\mu \mathrm{g} \cdot \min ^{-1} \cdot 40 \mathrm{~cm}^{-1}\right)=$ FRs $\times$ protein $s$, where protein $s$ is the protein concentration at the sampling point.

The results of the protein measurements will be presented according to three mathematical approaches: $(a)$ The measured protein concentrations in serum and jejunal perfusates. $(b)$ The absolute protein secretion rate across or from the jejunal mucosa was calculated as detailed above.

Table II. Numbers and Distributions of Ig-containing Cells in the Jejunal Lamina Propria of Control Patients

\begin{tabular}{|c|c|c|c|c|}
\hline & $\begin{array}{l}\text { Number } \\
\text { of counted cells }\end{array}$ & $\begin{array}{l}\text { Observed } \\
\text { surface }\end{array}$ & $\begin{array}{l}\text { Number } \\
\text { of cells } / \mathrm{mm}^{2}\end{array}$ & $\begin{array}{l}\text { Percentage } \\
\text { of all stained cells }\end{array}$ \\
\hline & & $\mathrm{mm}^{2}$ & & \\
\hline \multicolumn{5}{|l|}{ Classes } \\
\hline \multirow[t]{2}{*}{$\operatorname{Ig} A$} & $388^{*}$ & 0.18 & 2,282 & $79.6 \ddagger$ \\
\hline & $188-685 \S$ & $0.11-0.22$ & $1,268-3,478$ & $59.2-92.2$ \\
\hline \multirow[t]{2}{*}{ IgM } & 84 & 0.20 & 444 & $16.0 \ddagger$ \\
\hline & $30-126$ & $0.08-0.35$ & $153-770$ & $4.9-30.8$ \\
\hline \multirow[t]{2}{*}{ IgG } & 54 & 0.50 & 126 & $4.4 \ddagger$ \\
\hline & $5-85$ & $0.22-0.79$ & $22-124$ & $1.1-10.0$ \\
\hline \multicolumn{5}{|l|}{ Subclasses } \\
\hline \multirow[t]{2}{*}{$\lg A 1$} & 236 & 0.16 & 1,439 & $64.9^{\prime \prime}$ \\
\hline & $122-413$ & $0.07-0.26$ & $928-2,067$ & $61.3-69.6$ \\
\hline \multirow[t]{2}{*}{ IgA2 } & 132 & & 771 & $35.1^{11}$ \\
\hline & $58-240$ & & $547-1,100$ & $30.4-38.7$ \\
\hline \multirow[t]{2}{*}{$\operatorname{Ig} A 1+\operatorname{Ig} A 2$} & 368 & & 2,210 & \\
\hline & $180-653$ & & $1,498-3,617$ & \\
\hline
\end{tabular}

* Arithmetic mean per subject $(n=9)$, and for the two tissue specimens. $\ddagger$ Percentage of IgA + IgM + IgG. § Range. "Percentage of IgA1 + IgA2.

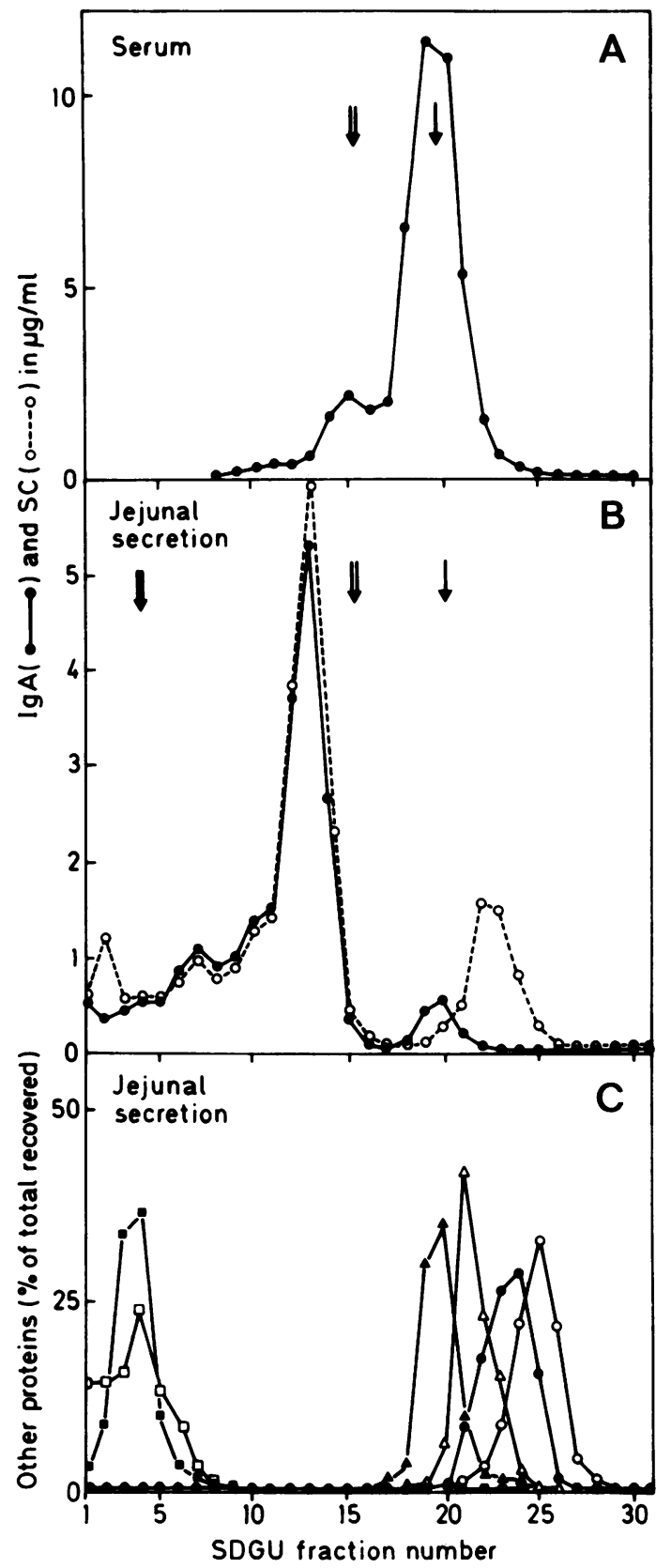

Figure 1. Simultaneous ultracentrifugation of serum (one control patient) and pooled jejunal perfusates of controls $(n=11)$. In serum $(A)$ and jejunal secretions $(B)$, the profile of $\operatorname{IgA}(\bullet-\bullet)$ measured by IRMA is corrected for the influence of the size of IgA; SC, $(0-\cdots--0)$. The lower profiles $(C)$ are those for the other proteins (ORO, ○- O; Alb, $\bullet-\bullet$; transferrin, $\Delta-\Delta$; IgG, $\Delta-\Delta$; $\alpha_{2} \mathrm{M}, \square-\square$; and IgM, $\left.\square-\square\right)$. The arrows indicate the sedimentation levels of $7 \mathrm{~S}$ m-IgA $(\rightarrow), 10.5 \mathrm{~S}$ d-IgA $(\rightarrow)$, and 19S IgM $(\rightarrow)$.

The value is the mean value of the four 20 -min periods of perfusion after the $1 \mathrm{~h}$ equilibration period. (c) The relative coefficient of excretion (RCE) of proteins is obtained from: RCE = [(protein in perfusate)/ 
Table III. Concentrations of Proteins in Serum and in Perfusate in Normal Individuals

\begin{tabular}{|c|c|c|c|c|c|c|c|c|c|c|}
\hline & Alb & ORO & Transf & $\operatorname{IgG}$ & $\operatorname{IgE}$ & $m-\lg A$ & p-IgA & $\mathrm{SC}^{*}$ & $\alpha_{2} \mathrm{M}$ & IgM \\
\hline $\begin{array}{l}\text { Serum } \\
\qquad(m g / m l)\end{array}$ & $\begin{array}{l}41.3 \ddagger \\
36.3-46.0 \S\end{array}$ & $\begin{array}{l}0.8 \\
0.5-1.7\end{array}$ & $\begin{array}{l}3.2 \\
2.6-4.2\end{array}$ & $\begin{array}{l}13.1 \\
8.9-19.3\end{array}$ & $\begin{array}{l}0.6 \times 10^{-3} \\
0.06 \times 10^{-3}-17.3 \times 10^{-3}\end{array}$ & $\begin{array}{l}2.2 \\
1.4-4.7\end{array}$ & $\begin{array}{c}0.3 \\
0.1-1.4\end{array}$ & - & $\begin{array}{l}2.0 \\
1.3-3.7\end{array}$ & $\begin{array}{l}1.0 \\
0.6-1.8\end{array}$ \\
\hline $\begin{array}{l}\text { Perfusate } \\
\quad(\mu \mathrm{g} / \mathrm{ml})\end{array}$ & $\begin{array}{l}14.9 \\
4.9-56.8\end{array}$ & $\begin{array}{l}0.4 \\
0.1-1.2\end{array}$ & $\begin{array}{l}1.3 \\
0.5-3.6\end{array}$ & $\begin{array}{c}3.8 \\
1.9-9.7\end{array}$ & $\begin{array}{l}0.2 \times 10^{-3} \\
0.02 \times 10^{-3}-4.05 \times 10^{-3}\end{array}$ & $\begin{array}{l}2.0 \\
0.5-4.8\end{array}$ & $\begin{array}{l}29.6 \\
4.0-54.7\end{array}$ & $\begin{array}{l}28.5 \\
4.8-89.9\end{array}$ & $\begin{array}{l}0.5 \\
0.3-1.5\end{array}$ & $\begin{array}{l}2.2 \\
0.6-4.5\end{array}$ \\
\hline
\end{tabular}

* Total free and Ig-bound SC. $¥$ Antilog of mean of log values $(n=11) . \quad \S$ Range.

(protein in serum)]/[(albumin in perfusate)/(albumin in serum)]. RCE was calculated for each 20 -min period. Mean values were then calculated for the entire period. This coefficient, already used by Delacroix et al. (23) to analyze the parameters of secretion of proteins in human bile and saliva, and in dog, rat, and rabbit bile (36), is by definition 1 for Alb. It expresses the secretion rate independently from the concentration of proteins in the serum and from the net water output in the secretion. If all serum proteins were secreted according to the same transport mechanism as for Alb, without any influence of their individual physical or chemical properties, RCE should always average one.

All data are presented as geometric mean and range, except for water and electrolyte movements and immunohistochemistry, where arithmetic means \pm SD were used. Results were compared by means of the nonparametric Wilcoxon's test for paired values (37).

\section{Results}

Immunohistochemical studies. The distribution of IgA-, IgA subclasses-, IgM-, and IgG-containing cells in the jejunal lamina propria are listed in Table II. Densities were measured per $\mathrm{mm}^{2}$ of lamina propria. The lamina propria accounted for $\sim 43 \%$ of the total mucosa. The sum of IgA1- plus IgA2-containing cells averaged $89-139 \%$ (mean equals $99 \%$ ) of the IgA-containing cells that were counted on serial sections of the same tissue specimen. Less than 10 out of 3,250 cells were found double stained using the double tracing procedure. In three peripheral lymph nodes, IgA2 represented $24.2,25.2$, and $25.7 \%$, respectively, of the total number of IgA-containing cells.

Molecular size of proteins and IgA subclasses in jejunal secretion of controls. IgA in control sera resolved in a minor peak (7.2-22.4\%, mean equals $11.5 \%)$ of $10.2 \mathrm{~S}$ dimeric-IgA (dIgA) and a predominant peak of $7 \mathrm{~S}$ m-IgA (Fig. $1 A$ ). The perfusate showed a major peak (80.4-97.5\%, mean equals $92.5 \%$ ) of $11 \mathrm{~S}$ and heavier p-IgA (Fig. $1 \mathrm{~B}$ ). SC in perfusate samples (Fig. $1 B$ ) sedimented with p-IgA (83.3-99.3\%, mean equals $91.5 \%$ ) and in the $4.5 \mathrm{~S}$ position corresponding to free SC (mean equals $8.5 \%$ ). SC-free p-IgA could not be detected in the perfusate.

All other proteins studied in the perfusate (Fig. $1 C$ ) sedimented as homogeneous peaks, with sedimentation coefficients similar to those usually observed in the serum. Thus, there was no evidence of proteolysis. IgA2 contributed from 15 to $31 \%$ (mean equals $23 \%$ ) of total IgA in the serum vs. $27-48 \%$ (mean equals $35 \%)$ in the perfusate $(P<0.01)$. For each individual, the percentage of IgA2 was greater in the perfusate than in the serum.
Protein concentrations and absolute jejunal secretion rates in controls. Protein concentrations in serum and perfusate samples are listed in Table III. In the perfusate, SC and p-IgA were present at greater concentration than all other proteins $(P$ $<0.01$ ). Polymeric-IgA contributed $79 \%$ of total Igs in the perfusate, $(\operatorname{IgG} / \mathrm{p}-\operatorname{IgA}=0.13)$ but contributed only $2 \%$ in the serum $(\mathrm{IgG} / \mathrm{p}-\mathrm{IgA}=44)$. Absolute secretion rates of proteins from the jejunal mucosa are shown in Fig. 2. About $217 \mu \mathrm{g}$ of p-IgA, 35 $\mu \mathrm{g}$ of $\mathrm{IgG}$, and $15 \mu \mathrm{g}$ of $\mathrm{m}$-IgA were secreted per minute into the $40-\mathrm{cm}$ long perfused segment. Within the successive $20-\mathrm{min}$ period samples from the 11 controls, the mean coefficient of variation of secretion rates ranges from $13 \%(6-32 \%)$ for IgM to $20 \%(6-39 \%)$ for IgG.

$R C E$ of proteins in controls. Two groups of proteins could be recognized when protein RCEs were calculated (Fig. 3). In the first group of proteins (Fig. 3, open columns and dotted

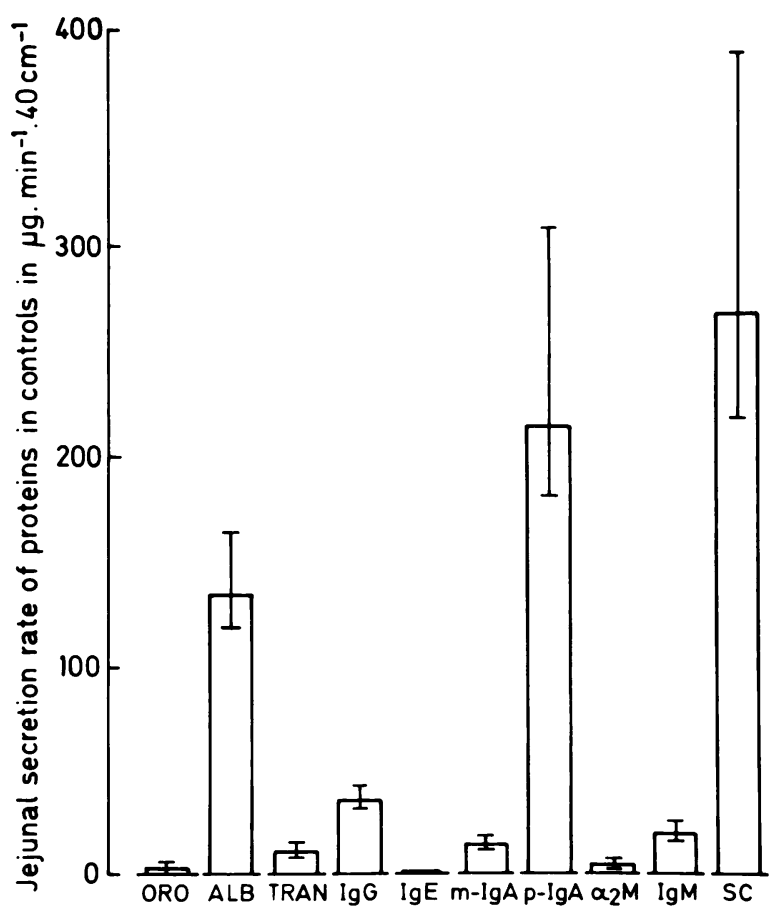

Figure 2. Jejunal secretion rate of various proteins in controls $(n$ $=11$ ) measured by segmental perfusion of the jejunum. Columns represent geometric mean $\pm \mathrm{SE}$ of the geometric mean. 


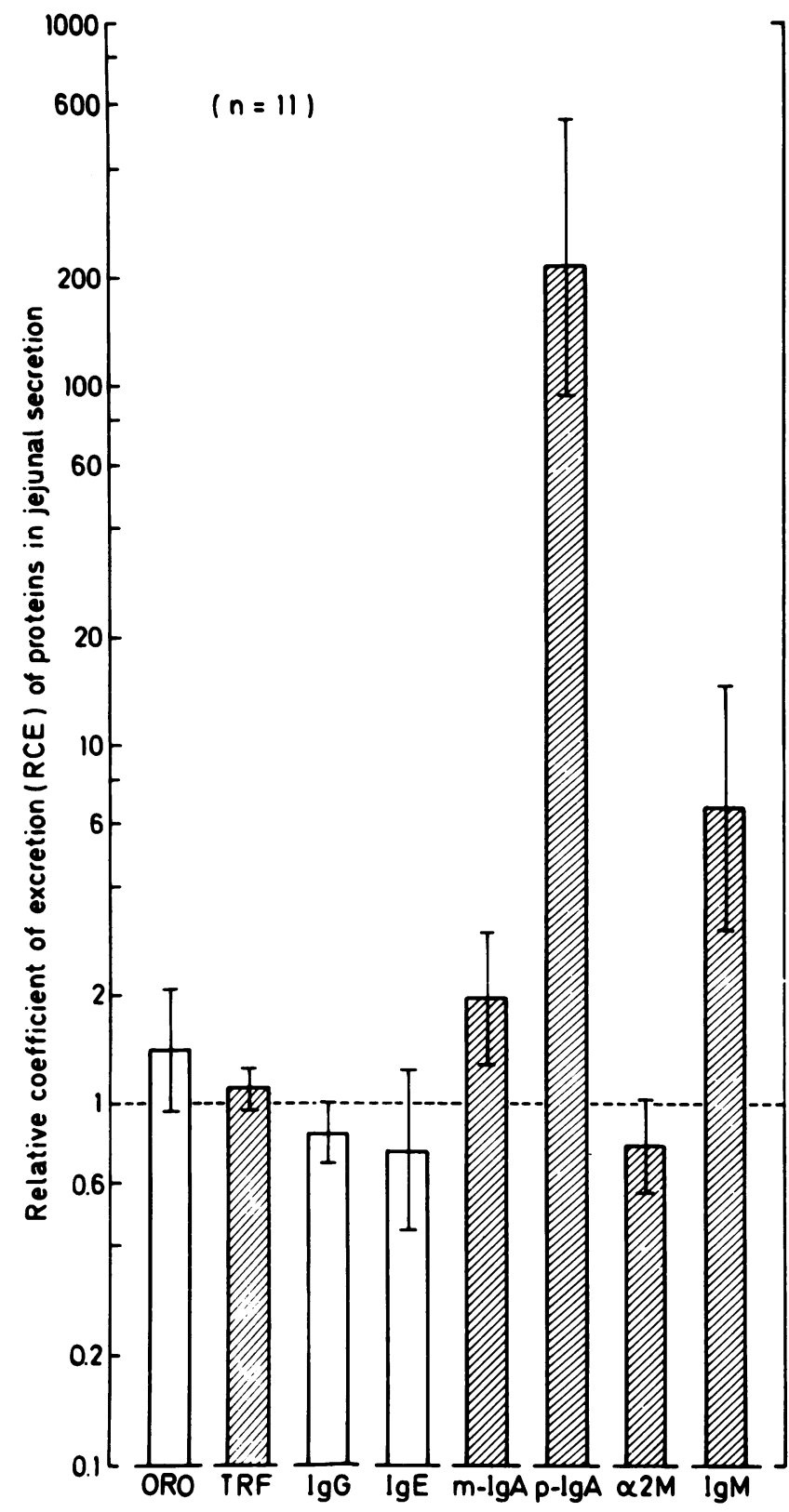

Figure 3. RCE of various proteins in jejunal secretion. Geometric means \pm SD are shown by columns. The horizontal dotted line represents the RCE of albumin, taken as a unit. Empty columns represents the proteins for which RCE values appear inversely related to their molecular weight. TRF, transferrin.

line), RCE values decreased as the protein molecular weight increased. The RCE values obtained were: 1.41 for ORO, which was $>1.0$ for $\mathrm{Alb}$, and $>0.83$ for $\mathrm{IgG}$, which was $\cong 0.74$ for IgE (all $P<0.05$ ). However, for all other proteins studied, no inverse relationship between RCE values and MW was observed. For example, transferrin $(85,000 \mathrm{~mol} \mathrm{wt})$ had an RCE value of 1.11 greater than the RCE of Alb $(65,000 \mathrm{~mol} \mathrm{wt}, P<0.05)$. Similarly, other RCE values observed were: 1.98 for $\mathrm{m}$-IgA, which was $>\operatorname{IgG}(P<0.001), 0.77$ for $\alpha_{2} \mathrm{M}$, which was $\cong \operatorname{IgG}$ and $\operatorname{IgE}$, and 6.7 for IgM and 218 for p-IgA, which was $>$ RCEs of all other proteins of lower molecular weight $(P<0.001)$.

Radioisotopic studies. As shown for patient 2 in Fig. 4, the major part $(\sim 70 \%)$ of the ${ }^{125}$ I-radioactivity in the perfusate which had been ultrafiltrated corresponded to the peak of unlabeled p-IgA seen in SDGU. The results for the two individuals are listed in Table IV. For Alb, specific activities in serum and perfusate were similar (specific activity ratios equal 1.11 and 0.90), whereas for p-IgA, specific activities in perfusate were much lower than in serum (specific activity ratio equals 0.048 and 0.013 ). In other words, $\sim 100 \%$ of Alb in jejunal secretion was derived from plasma, whereas plasma p-IgA accounted only for 4.8 and $1.3 \%$ of jejunal p-IgA.

When the RCE for p-IgA was calculated for these two individuals, considering only their plasma-derived p-IgA, values of 9.19 and 2.92 were obtained. This indicates that their plasmato-jejunum transport of $\mathrm{p}$-IgA was approximately nine and three times more rapid than the transport of Alb.

Jejunal secretion of Igs in the patient lacking lamina propria IgA and IgM plasmacytes. The sedimentation profiles of IgA and $\mathrm{SC}$ from the deficient patient are shown in Fig. 5. In serum, p-IgA contributed $6 \%$ of total IgA, a figure slightly lower than the lowest value obtained in controls. In the perfusate, IgA resolved in a major peak of $\mathrm{m}$-IgA $(82 \%)$ and a minor peak of $11 \mathrm{~S} \mathrm{p}$-IgA (18\%). SC occurred predominantly $(98 \%)$ in the free form. These profiles are in sharp contrast to those observed in controls (Fig. 1).

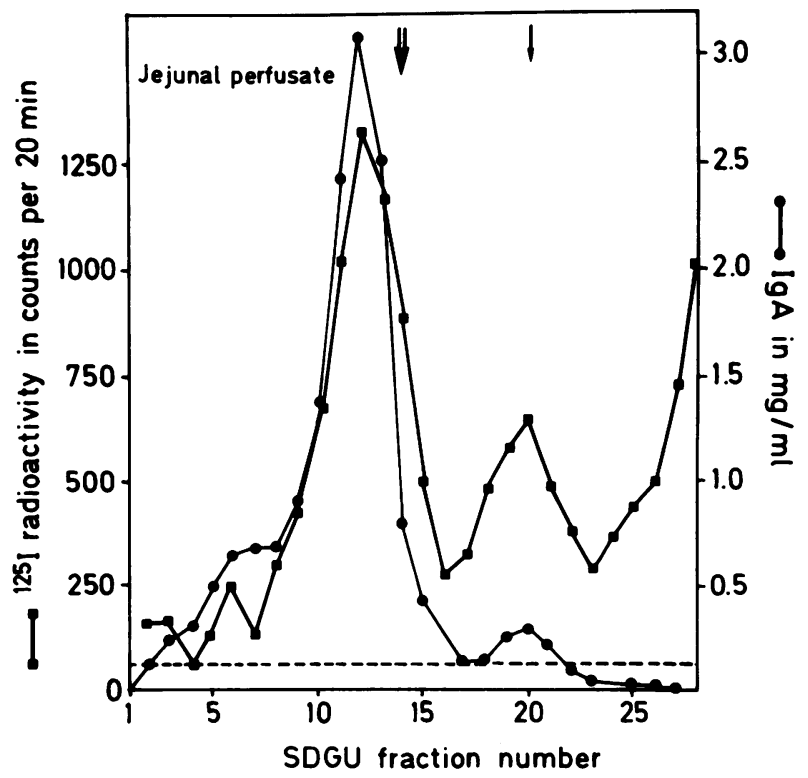

Figure 4. Sedimentation profile of unlabeled IgA $(\bullet)$ and ${ }^{125}$ I-radioactivity (a) recovered in the jejunal perfusate of patient 2 . Arrows indicate the sedimentation levels of unlabeled $\mathrm{m}-\operatorname{IgA}(7 \mathrm{~S}, \rightarrow)$, and d-IgA $(10.5 \mathrm{~S}, \rightarrow)$ tracers). Dashed line: $2 \mathrm{SD}$ above the ${ }^{125} \mathrm{I}$ background. 


\begin{tabular}{|c|c|c|c|c|}
\hline & \multicolumn{2}{|l|}{ Patient 1} & \multicolumn{2}{|l|}{ Patient 2} \\
\hline & Albumin $\left({ }^{13} \mathrm{I}\right)$ & p-IgA $\left({ }^{125} I\right)$ & Albumin $\left({ }^{131} I\right)$ & p-IgA $\left({ }^{125} I\right.$ \\
\hline \multicolumn{5}{|l|}{ Serum: } \\
\hline \multicolumn{5}{|l|}{ TCA precipitable radioactivity } \\
\hline (Counts $/ 20 \mathrm{~min} / 3 \mathrm{ml})^{*}$ & 177,090 & 14,228 & 98,519 & 86,116 \\
\hline Concentration $(m g / m l)$ & 41.46 & 0.37 & 36.33 & 0.31 \\
\hline Specific activity (Counts/20 $\mathrm{min} / \mathrm{mg}$ ) & 4,271 & 38,454 & 2,712 & 276,013 \\
\hline \multicolumn{5}{|l|}{ Perfusateł: } \\
\hline \multicolumn{5}{|l|}{ TCA precipitable radioactivity } \\
\hline (Counts/20 min/3 ml)* & 8,129 & 5,431 & 3,615 & 9,950 \\
\hline Concentration $(m g / m l)$ & 1.72 & 2.96 & 1.48 & 2.84 \\
\hline Specific activity (Counts $/ 20 \mathrm{~min} / \mathrm{mg}$ ) & 4,726 & 1,835 & 2,444 & 3,507 \\
\hline Perfusate/serum specific activity & 1.11 & 0.048 & 0.90 & 0.013 \\
\hline \multicolumn{5}{|l|}{ Relative coefficient of excretion } \\
\hline Total RCE§ (local + serum derived) & 1 & 193 & 1 & 225 \\
\hline Serum-derived RCE $\ddagger$ & 1.11 & 9.19 & 0.90 & 2.92 \\
\hline
\end{tabular}

* In serum, TCA precipitable counts were $>88 \%$ of total radioactivity. In perfusates, precipitable counts accounted for $>80 \%$ of total counts for Alb and 59 (patient 1 ) and $64 \%$ (patient 2 ) for p-IgA. $¥ 100$-fold concentrated sample. $\$$ Total RCE equals ([protein] perfusate/[protein] serum)/([Alb]perfusate/[Alb]serum). $¥$ Serum derived RCE equals (total RCE) $\times$ (perfusate/serum specific activity).

Serum concentrations and jejunal secretions rates for Alb, IgG, $\alpha_{2} \mathrm{M}, \mathrm{SC}$, IgA, and IgM in the deficient patient are listed in Table $\mathrm{V}$ (all in absolute values and in percentage of mean control values). In the serum, IgA and IgM concentrations were mildly decreased. By contrast, jejunal secretion rates of $\mathrm{p}-\operatorname{IgA}$ and IgM were strongly depressed at $0.2 \%$ of the control values. The secretion rate of $\mathrm{m}-\operatorname{Ig} \mathrm{A}$ was less depressed at $13 \%$ of the controls. Secretion rates of other proteins, including SC, were in the upper range of control values, which are shown in Fig. 2. IgA2 percentages (Table $\mathrm{V}$ ) were below the control range in both serum and perfusate and were similar in both fluids, which contrasted with results obtained in controls.

When the RCEs for p-IgA as well as $\mathrm{m}-\operatorname{IgA}$ and $\operatorname{IgM}$ were calculated in this deficient individual (Table V), values of 1.24 , 0.64 , and 0.016 were obtained, respectively. Thus, only $\mathrm{p}-\operatorname{IgA}$ was found to be selectively transported from plasma, as compared with Alb, whereas the transport of plasma IgM appeared to be greatly affected by the molecular weight of this protein. RCE values for $\mathrm{p}$-IgA and IgM were $\cong 0.5 \%$ of control values. This again indicates that in normal individuals, local production of p-IgA as well as that of IgM contributes the majority of these Ig in the jejunal lumen. Fig. 6 summarizes the RCE data that was obtained in the deficient patient, (shaded columns for $\mathrm{m}$ IgA, p-IgA, and IgM), in radioisotopic studies (shaded columns for Alb and p-IgA), and in controls (points). Plasma-to-jejunum transport of Alb, m-IgA, and IgM were inversely related to their molecular weights, as observed in controls for ORO, Alb, IgG, and IgE. By contrast, plasma-to-jejunum transport of p-IgA was $\cong 3.2$ times (mean RCE in the deficient individual and in isotopic studies) more rapid than the transport of Alb, exceeding by $\sim 15$ times the transport rate (RCE equals 0.2 ) expected from its molecular weight (see regression line). It is interesting to notice that $\alpha_{2}$ M's RCE ( 0.77$)$ in controls also greatly exceeded the value expected $(0.02)$ from its molecular weight.

\section{Discussion}

This study allowed the assessment of three main parameters of protein secretion from the jejunal mucosa: the absolute protein secretion rate, the relative coefficient of protein excretion, and the relative contributions of plasma-derived and locally produced IgA (and IgM). These parameters were characterized with greatly reduced sources of errors. The distribution of Ig-containing cells in the lamina propria of our control group was similar to that previously observed in normal individuals $(8,38)$. The use of an occluding balloon in the segmental perfusion of the gut prevented contamination or reflux of the perfusate samples. In our procedure, only minor movements of water and electrolytes were induced. The artefacts, due to the occlusion of the gut lumen with alteration of gut vascularization, were found unsignificant in a preliminary study (22). No proteolysis was observed in the perfusate, and protein measurements were reproducible over successive periods of time. Both $\mathrm{m}$ - and $\mathrm{p}$ - $\mathrm{IgA}$ were considered separately, with appropriate correction for the influence of their size in IgA immunoassays.

Analysis of protein concentrations in jejunal perfusates of controls demonstrated a large predominance of $\mathrm{p}-\mathrm{IgA}$ and SC. Polymeric-IgA accounted for $92 \%$ of jejunal $\operatorname{IgA}$ and was entirely 


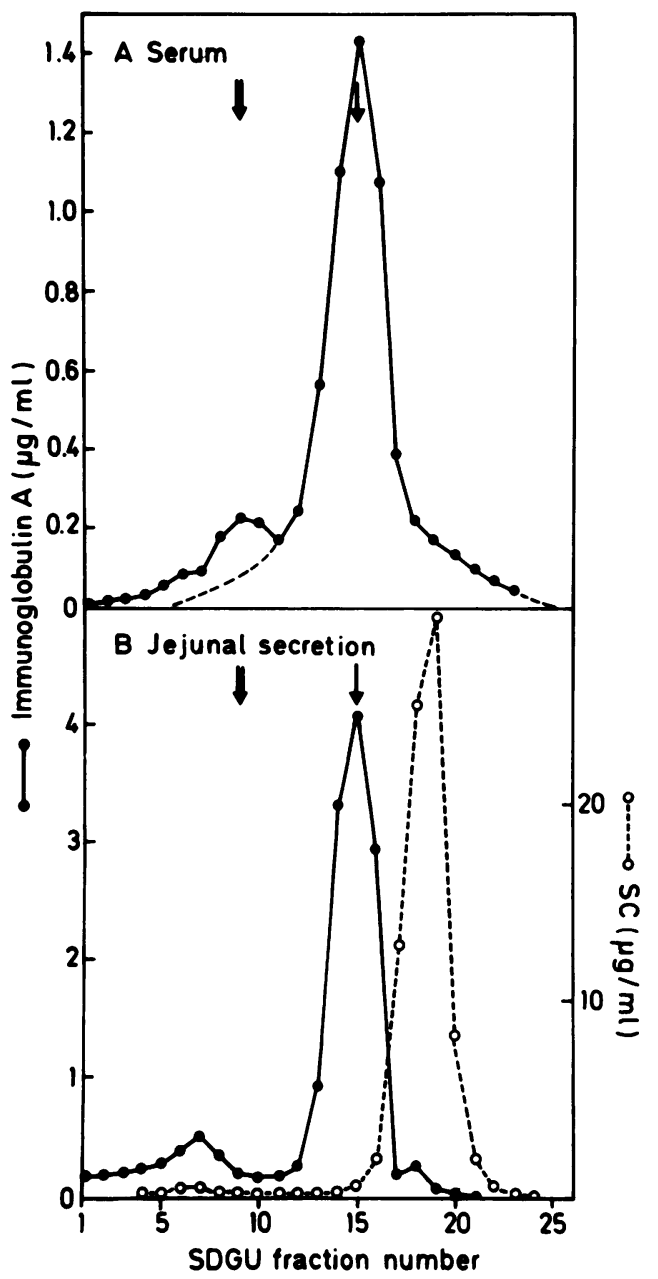

Figure 5. Simultaneous ultracentrifugation of serum and jejunal perfusate of the patient lacking IgA and IgM plasmacytes in his jejunal lamina propria. Arrows indicate the sedimentation levels of $7 \mathrm{~S} \mathrm{~m}$-IgA $(\rightarrow)$ and $10.5 S$ d-IgA $(\rightarrow)$. The jejunal IgA and SC profiles show that $\mathrm{m}$-IgA and free SC are in large excess compared with the control group (see Fig. 1).

bound to SC. SC was also present in the free form. The serum concentration of p-IgA was $\sim 50$ times lower than that of IgG, whereas the p-IgA concentration in jejunal perfusates was eightfold greater than that of IgG, and usually exceeded that of Alb. This is in contrast to results of previous studies $(1,39)$. In these studies, IgG and IgA concentrations in upper bowel secretions were roughly similar, and lower than that of Alb. This may have been due to a contamination with bile, which contains similar amounts of IgG and IgA and a larger amount of albumin (23). The separate measurement of $\mathrm{m}$ - and $\mathrm{p}$-IgA, with correction for size effects in IgA IRMA, could also explain the difference between the present and previous studies (40).

In the deficient patient, although jejunal concentrations of p-IgA and IgM were greatly reduced, SC concentration was similar to the mean control value. However, SC in the perfusate of this patient occurred almost entirely in the free form. This observation again indicates that the jejunal secretion of SC occurs independently of the amount of polymeric Ig present at the basolateral surface of the gut epithelial cells (41).

The absolute secretion rates of proteins into the jejunum could be calculated from the perfusate protein concentration and the perfusion flow rate at the sampling point. In the control individuals, the total amount of p-IgA secreted from $40 \mathrm{~cm}$ of perfused jejunum under fasting conditions averages $217 \mu \mathrm{g} /$ min, or about $312 \mathrm{mg} / \mathrm{d}$. This value is 1.5 and 6.5 times greater, respectively, than the total secretion rates of $\mathrm{p}$-IgA measured in saliva $(\sim 193 \mathrm{mg} / \mathrm{d})$ and bile $(\sim 54 \mathrm{mg} / \mathrm{d})$ using the same assays and standards (23). It can therefore be concluded that jejunal secretion provides the largest amount of $\mathrm{p}$ - $\operatorname{IgA}$ present in the upper small bowel, with only a minor contribution of bile. This conclusion illustrates another aspect of the species differences that was observed between the IgA systems of humans and rats $(23,13,36)$. Rat hepatocytes actively transport $p$-IgA from plasma into bile (42), and deliver to the intestine 50 times more p-IgA ( $35 \mathrm{mg} / \mathrm{kg}$ per d) than does human bile (36). Due to this liver pathway, plasma-derived biliary p-IgA in rat contributes the majority ( $90 \%)$ of total IgA in upper intestinal washings (43).

We further analyzed our data using the RCE calculation. This parameter expresses the protein secretion rate independently of the critical influence of the serum protein concentration. It allowed the distinction of two main groups of proteins in the jejunal perfusate with respect to the mechanism of their secretion. For ORO, Alb, IgG, and IgE in controls, and for $\mathrm{m}-\operatorname{IgA}$ and especially IgM in the deficient patient, RCE values (Fig. 6) pointed to a predominant secretion by molecular weight-affected seepage from plasma. This observation for IgE contrasts with previous suggestions of a more selective secretion of this Ig (44, 45). For another group of proteins, transferrin, m-IgA, $\alpha_{2} M, p-$ IgA, and IgM, RCE in controls exceeded the value expected from a molecular weight-affected transport from plasma. RCE of transferrin (1.11) slightly but significantly exceeded that of the smaller Alb. The RCE of $\alpha_{2} \mathrm{M}(0.7)$, similar to that of the smaller IgG, was 50-fold greater than that of IgM in the deficient patient. Local production of transferrin $(46,47)$ and of $\alpha_{2} M$ (48) and receptor-mediated transepithelial transport of transferrin (49) could play a role in the more selective secretion of these proteins from the jejunal mucosa. Further analyses are needed to assess the reality and physiological relevance of these factors. According to their RCE, $m-\operatorname{IgA}, \operatorname{IgM}$, and $\mathrm{p}$-IgA in controls were, respectively, secreted from the jejunal mucosa twofold, sixfold, and 216-fold more selectively than Alb. These results demonstrate that local production in the lamina propria and SC-mediated transepithelial transport of $\mathrm{p}-\operatorname{IgA}$ and $\operatorname{IgM}$ play a major role in enhancing the secretion of these Ig from the jejunal wall.

Analysis of the distribution of IgA subclasses demonstrated a higher proportion of IgA2 (35\%) in all control perfusate samples when compared with the corresponding serum samples. This 
Table V. Parameters of Jejunal Secretion of Proteins in the Patient Lacking Jejunal IgA and IgM Plasmacytes

\begin{tabular}{|c|c|c|c|c|c|c|c|c|}
\hline & Alb & IgG & m-lgA & p-lgA & $\alpha_{2} \mathbf{M}$ & IgM & SC & $\operatorname{IgA} 2^{*}$ \\
\hline $\begin{array}{l}\text { Protein concentra } \\
\qquad(\mathrm{mg} / \mathrm{ml})\end{array}$ & $\begin{array}{l}38.2 \ddagger \\
(92)\end{array}$ & $\begin{array}{c}10.2 \\
(78)\end{array}$ & $\begin{array}{l}0.44 \\
(20)\end{array}$ & $\begin{array}{l}0.05 \\
(17)\end{array}$ & $\begin{array}{l}1.3 \\
(64)\end{array}$ & $\begin{array}{l}0.5 \\
(52)\end{array}$ & - & $\begin{array}{l}0.13 \\
(55)\end{array}$ \\
\hline $\begin{array}{l}\text { Protein jejunal se } \\
\mu \mathrm{g} / \mathrm{min} / 40 \mathrm{~cm}\end{array}$ & $\begin{array}{l}248.8 \\
(187)\end{array}$ & $\begin{array}{l}66.0 \\
(186)\end{array}$ & $\begin{array}{l}2.0 \\
(13)\end{array}$ & $\begin{array}{l}0.4 \\
(0.2)\end{array}$ & $\begin{array}{l}8.0 \\
(158)\end{array}$ & $\begin{array}{l}0.05 \\
(0.2)\end{array}$ & $\begin{array}{l}327.6 \\
(120)\end{array}$ & $\begin{array}{l}0.12 \\
(36)\end{array}$ \\
\hline Protein RCE & $\begin{array}{c}1 \\
(100)\end{array}$ & $\begin{array}{r}0.99 \\
(119)\end{array}$ & $\begin{array}{l}0.64 \\
(32)\end{array}$ & $\begin{array}{c}1.24 \\
(0.6)\end{array}$ & $\begin{array}{l}1.00 \\
(130)\end{array}$ & $\begin{array}{l}0.016 \\
(0.5)\end{array}$ & - & - \\
\hline
\end{tabular}

* Ratio of IgA2/(IgA1 + IgA2). ¥ Mean value of the four 20-min samples in the deficient patient. Values in parentheses are percentages of the mean value obtained in control individuals.

observation, although demonstrating less disparity between $\operatorname{IgA} 1 /$ IgA2 ratios in serum and secretions than frequently stated, extends results already obtained for milk (32) and several other external secretions (33). Similarly, the proportion of IgA2-con-

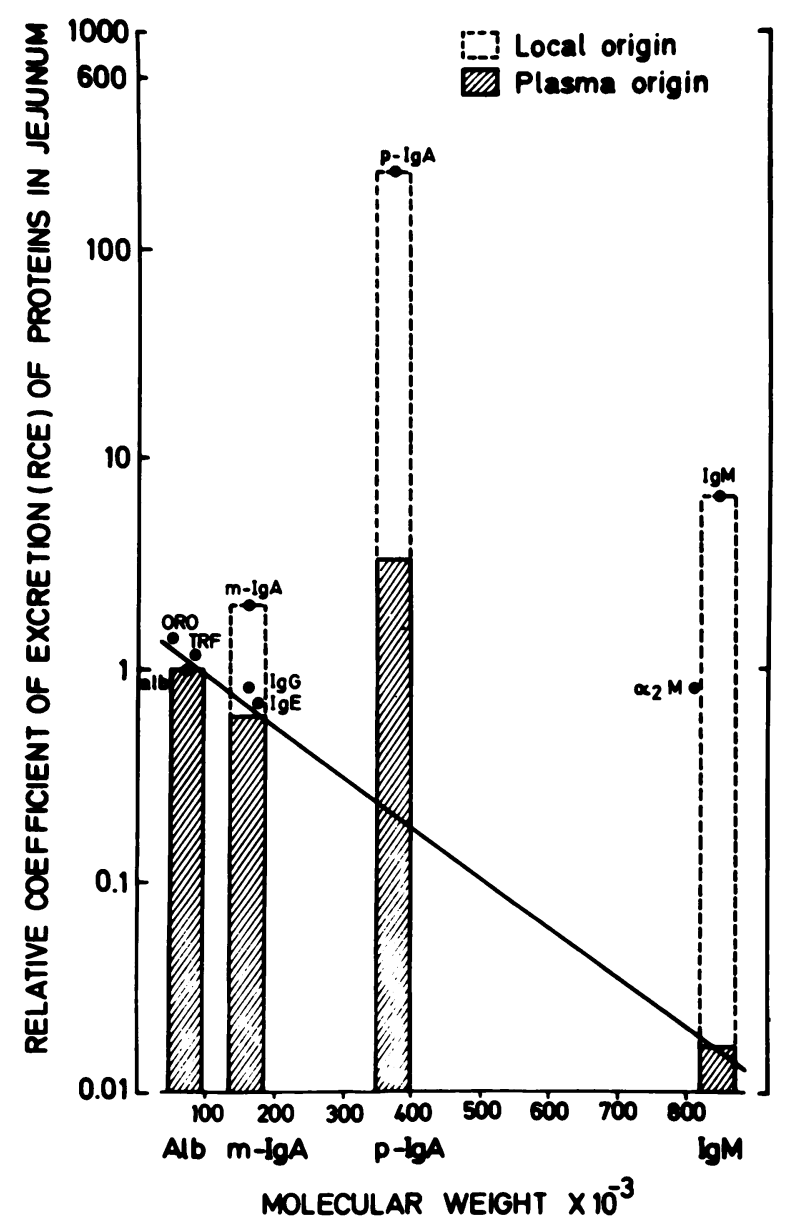

taining cells in the jejunal lamina propria was also greater than that in peripheral lymph nodes, as already observed when gut lamina propria (49) was compared with bone marrow $(50,51)$ using single-staining procedures. The similarity between the figures observed in jejunal secretion vs. serum, and in cells of lamina propria vs. peripheral lymph nodes or bone marrow, indirectly points to a large contribution of locally produced IgA to the IgA present in the gut lumen.

The contributions of plasma vs. local intestinal production of IgA (and IgM) in jejunal secretions were directly investigated with radioisotopes or were derived from comparison between $\mathrm{RCE}$ results in the deficient patient and those obtained in controls. Calculation of the specific activities of ${ }^{125} \mathrm{I}-\mathrm{p}-\mathrm{IgA}$ in serum and perfusate simultaneously demonstrated that only a minority ( 2 and $5 \%$ ) of jejunal p-IgA is derived from plasma, vs. $\cong 100 \%$ for Alb. In the deficient patient, RCE of p-IgA was only $0.6 \%$ of the mean control value, which again indicated that in normal individuals almost all jejunal p-IgA $(\sim 98 \%)$ comes from local production in the gut wall. In the present study we calculated an RCE for plasma-to-jejunum transport of p-IgA of $\sim 3.2$ (mean from isotopic experiments and from the deficient patient). This value is close to those previously recorded for the transport of plasma p-IgA into bile (RCE equals 4.5) and into saliva (RCE equals 4.4) (23). It demonstrates a small, selective plasma-tojejunum transport of $\mathrm{p}$-IgA $(\sim 5$-fold more rapid than for

Figure 6. Transport of plasma proteins into the jejunum as assessed by their RCE. RCE values for ORO, Alb, transferrin (TRF), IgG, $\operatorname{IgE}, \mathrm{m}-\mathrm{IgA}, \mathrm{p}-\mathrm{IgA}, \alpha_{2} \mathrm{M}$, and IgM in controls are shown by points (๑). RCE calculated for plasma-derived Alb, m-IgA, p-IgA, and IgM are shown by striped columns. Their values were obtained in radioisotopic studies (Alb and p-IgA), and from the patient deficient in jejunal IgA and IgM plasmacytes (p-IgA, m-IgA, and IgM). Open columns represent the contribution of locally produced p-IgA, m-IgA, and IgM. A regression line $(r=0.83)$ joins the RCE values that were obtained for ORO, Alb, IgG, IgE, and plasma-derived m-IgA and IgM to outline the influence of the molecular weight of these proteins on their transport from plasma across the jejunal mucosa. 
m-IgA). Its absolute amount can be estimated at $\sim 6 \mathrm{mg} / \mathrm{d}$ or $\sim 0.08 \mathrm{mg} / \mathrm{kg}$ per $\mathrm{d}$ for the first $40 \mathrm{~cm}$ of jejunum. This is $<2 \%$ of the fraction of the intravascular pool of $\mathrm{p}-\mathrm{IgA}$ that is cleared daily from plasma $(4.5 \mathrm{mg} / \mathrm{kg}$ per d) (13). In the deficient patient, the RCE for m-IgA (0.6) was similar to that of IgG and accounted for $32 \%$ of the mean control value. Thus $\mathrm{m}$-IgA does not appear to be selectively transported across the jejunal wall, and its local production in the lamina propria probably contributes for greater than half of its total secretion. For IgM, the RCE in the deficient patient was extremely low (0.016), 400 -fold smaller than in controls. This result indicates that the plasma-to-jejunum transport of IgM, despite the presence of epithelial SC, is dramatically affected by its molecular weight, and that local synthesis in the gut wall contributes $>99 \%$ of the jejunal secretion of IgM in normal individuals.

\section{Acknowledgments}

We gratefully acknowledge the excellent technical assistance of C. Franchisseur, M. Bovet, M. Lefever, and M. Rongier for perfusion procedures and R. Meykens, J. P. Dehennin, and J. Naze-De Mets for protein measurements. Dr. C. Magnusson (International Institute of Cellular and Molecular Pathology; Brussels) kindly performed IgE measurements.

The work was supported in part by grants 3.4504 .70 and 220991 of the Fonds de la Recherche Scientifique Médicale (FNRS), Brussels, Belgium.

\section{References}

1. Schultze, H. E., and J. F. Heremans. 1966. Proteins of intestinal secretions. In Molecular Biology of Plasma Proteins. Vol. 1. M. Sela, editor. Elsevier Publishing Co., Amsterdam. 789-815.

2. Tomasi, T. B., E. M. Tan, A. Salomon, and R. A. Prendergast. 1965. Characteristics of an immune system common to certain external secretions. J. Exp. Med. 121:101-124.

3. Brandtzaeg, P. 1981. Transport models for secretory IgA and secretory IgM. Clin. Exp. Immunol. 44:221-232.

4. Nagura, H., P. K. Nakane, and W. R. Brown. 1979. Translocation of dimeric IgA through neoplastic colon cells in vitro. J. Immunol. 123:2359-2363.

5. Heremans, J. F. 1974. Immunoglobulin A. In The Antigens II. M. Sela, editor. Academic Press, Inc., New York. 463-482.

6. Brown, W. R., R. Isobe, P. K. Nakane, and B. Pacini. 1977. Studies on translocation of immunoglobulins across intestinal epithelium. IV. Evidence for binding of IgA and IgM to secretory component in intestinal epithelium. Gastroenterology. 73:1333-1339.

7. Lamm, M. E. 1976. Cellular aspects of immunoglobulin A. Advances in Immunology. Academic Press, Inc., New York. 22:260-272.

8. Crabbé, P. A., and J. F. Heremans. 1966. The distribution of immunoglobulin-containing cells along the human gastro-intestinal tract. Gastroenterology. 51:305-316.

9. Brandtzaeg, P. 1973. Two types of IgA immunocytes in man. Nat. New Biol. 243:142-143.

10. Radl, J., H. R. E. Schuit, J. Mestecky, and W. Hijmans. 1974. The origin of monomeric and polymeric forms of IgA in man. $A d v$. Exp. Med. Biol. 45:57-65.

11. Kutteh, W. H., S. J. Prince, and J. Mestecky. 1982. Tissue origins of human polymeric and monomeric IgA. J. Immunol. 128:990-995.

12. MacDermott, R. P., D. L. Delacroix, G. S. Nash, M. J. Bertovitch,
R. F. Morhmam, and J. P. Vaerman. 1984. An increased percentage of monomeric $\operatorname{IgA}(\mathrm{m}-\operatorname{IgA})$ and $\operatorname{IgA}$ subclass $1(\operatorname{IgA} 1)$ is present in the IgA spontaneously secreted by isolated intestinal mononuclear cells from inflammatory bowel disease patients. Gastroenterology. 86:1169. (Abstr.)

13. Delacroix, D. L., K. B. Elkon, A. P. Geubel, H. F. Hodgson, C. Dive, and J. P. Vaerman. 1983. Changes in size, subclass, and metabolic properties of serum immunoglobulin $A$ in liver diseases and in other diseases with high serum immunoglobulin A. J. Clin. Invest. 71:358367.

14. Alley, C. D., G. S. Nash, and R. P. MacDermott. 1982. Marked in vitro spontaneous excretion of IgA by human rib bone marrow mononuclear cells. J. Immunol. 128:2604-2608.

15. Brandtzaeg, P. 1977. Human secretory component. VI. Immunoglobulin-binding properties. Immunochemistry. 14:179-188.

16. Socken, D. J., and B. J. Underdown. 1978. Comparison of human, bovine and rabbit secretory component-immunoglobulin interactions. Immunochemistry. 15:499-506.

17. Crago, S. S., R. Kulhavy, S. J. Prince, and J. Mestecky. 1978. Secretory component on epithelial cells is a surface receptor for polymeric immunoglobulins. J. Exp. Med. 147:1832-1837.

18. Mostov, K. E., and G. Blobel. 1982. A transmembrane precursor of secretory component. The receptor for transcellular transport of polymeric immunoglobulins. J. Biol. Chem. 257:11816-11821.

19. Kühn, L. C., and J. P. Kraehenbuhl. 1982. The sacrificial receptor. Translocation of polymeric IgA across epithelia. Trends Biochem. Sci. 7:299-302.

20. Fortran, J. S., F. C. Rector, M. F. Ewton, N. Soter, and J. Kinney. 1965. Permeability characteristics of the human small intestine. J. Clin. Invest. 44:1934-1944.

21. Fortran, J. S. 1969. Segmental perfusion techniques. Gastroenterology. 56:987-989.

22. Rambaud, J. O., F. Duprey, O. Novel, J. Hostein, B. Delpech, and J. J. Bernier. 1981. Assessment of the accuracy of segmental perfusion under an occluding balloon for measuring the intrajejunal secretion of albumin and immunoglobulin A. Gut. 22:371-375.

23. Delacroix, D. L., H. J. F. Hodgson, A. McPherson, C. Dive, and J. P. Vaerman. 1982. Selective transport of polymeric IgA in bile. Quantitative relationship of monomeric and polymeric IgA, IgM and other proteins in serum, bile and saliva. J. Clin. Invest. 70:230-241.

24. Ritchie, R. F., C. A. Alper, J. Graver, N. Pearson, and C. Larson. 1973. Automated quantitation of proteins in serum and other biological fluids. Am. J. Clin. Pathol. 59:151-159.

25. Delacroix, D. L., J. P. Dehennin, and J. P. Vaerman. 1982. Influence of molecular size of IgA on its immunoassay by various techniques. II. Solid phase radioimmunoassays. J. Immunol. Methods. 48:327-337.

26. Masson, P. L., C. L. Cambiaso, D. Collet-Cassart, C. G. M. Magnusson, C. Richards, and C. J. M. Sindic. 1981. Particle counting immunoassay. Methods Enzymol. 74(Pt. C):106-139.

27. Magnusson, C. G. M., and P. L. Masson. 1982. Particle counting immunoassay of immunoglobulin $\mathrm{E}$ antibodies after their elution from allergosorbents by pepsin: an alternative to the radioallergosorbent test. J. Allergy Clin. Immunol. 70:326-336.

28. Delacroix, D. L., R. Meykens, and J. P. Vaerman. 1982. Influence of molecular size of IgA on its immunoassay by various techniques. I. Direct and reversed single radial immunodiffusion. Mol. Immunol. 19:297-305.

29. Delacroix, D. L., and J. P. Vaerman. 1982. Influence of molecular size of IgA on its immunoassay by various techniques. III. Immunonephelometry. J. Immunol. Methods. 51:49-55.

30. Vaerman, J. P., and J. F. Heremans. 1966. Subclasses of human 
immunoglobulin A based on differences in the alpha polypeptide chains. Science (Wash. DC). 153:647-649.

31. Feinstein, D., and E. C. Franklin. 1966. Two antigenically distinguishable subclasses of human $\gamma \mathrm{A}$ myeloma proteins differing in their heavy chains. Nature (Lond.). 212:1496-1498.

32. Grey, H. M., C. A. Abel, J. Yount, and H. G. Kunkel. 1968. A subclass of human $\gamma \mathrm{A}$-globulins ( $\gamma \mathrm{A} 2)$ which lacks the disulfide bonds linking heavy and light chains. J. Exp. Med. 128:1223-1236.

33. Delacroix, D. L., D. Dive, J. C. Rambaud, and J. P. Vaerman. 1982. IgA subclasses in various secretions and in serum. Immunology. 47:383-385.

34. Van Loghem, E., and J. Biewenga. 1983. Allotypic and isotypic aspects of human immunoglobulin A. Mol. Immunol. 20:1001-1007.

35. Delacroix, D. L., A. M. Denef, G. A. Acosta, P. C. Montgomery, and J. P. Vaerman. 1982. Immunoglobulins in rabbit hepatic bile: selective secretion of IgA and IgM, and active plasma-to-bile transfer of polymeric IgA. Scand. J. Immunol. 16:343-350.

36. Delacroix, D. L., G. Furtado-Barreira, B. de Hemptinne, J. Goudswaard, C. Dive, and J. P. Vaerman. 1983. The liver in the IgA secretory immune system. Dogs, but not rats and rabbits are suitable models for human studies. Hepatology. 3:980-988.

37. Snedecor, G. W., and W. G. Cochran, editors. 1978. Statistical Methods. The Iowa University Press. Ames, IA. Sixth ed. 128-132; 432436.

38. Brandtzaeg, P., and K. Baklien. 1976. Immunohistochemical studies of the formation and epithelial transport of immunoglobulins in normal and diseased human intestinal mucosa. Scand. J. Gastroenterol. 11(Suppl)36:1-45.

39. Bull, D. M., J. Bienenstock, and T. B. Tomasi. 1971. Studies on human intestinal immunoglobulin A. Gastroenterology. 60:370-380.

40. Hoj, L., E. Oddsson, and E. Krag. 1981. Secretion rate of intestinal immunoglobulins, complement factor $\mathrm{C} 3$, "acute phase" reactants, and albumin in the perfused ileum and jejunum of normal man. Acta Pathol. Microbiol. Scand. Sect. C Immunol. 89:229-234.
41. Nagura, H., P. K. Nakane, and W. R. Brown. 1980. Secretory component in immunoglobulin deficiency: an immunoelectron microscopic study of intestinal epithelium. Scand. J. Immunol. 12:359-363.

42. Vaerman, J. P., I. M. Lemaître-Coelho, J. N. Limet, and D. L. Delacroix. 1982. Hepatic transfer of polymeric IgA from plasma to bile in rats and other mammals: a survey. In Recent Advances in Mucosal Immunity. W. Strober, L. A. Hanson, and K. N. Sell, editors. Raven Press, NY. 231-248.

43. Lemaître-Coelho, I., G. D. F. Jackson, and J. P. Vaerman. 1978. Relevance of biliary IgA antibodies in rat intestinal immunity. Scand. J. Immunol. 8:459-463.

44. Brown, W. R., B. K. Borthisle, and S.-T. Chen. 1975. Immunoglobulin E (IgE) and IgE-containing cells in human gastrointestinal fluids and tissues. Clin. Exp. Immunol. 20:227-237.

45. Belut, D., D. A. Moneret-Vautrin, J. P. Nicolas, and J. P. Grilliat. 1980. IgE levels in intestinal juice. Dig. Dis. Sci. 25:323-332.

46. Soltys, H. D., and J. I. Brody. 1970. Synthesis of transferrin by human peripheral blood lymphocytes. J. Lab. Clin. Med. 75:250-257.

47. Johnson, G., P. Jacobs, and L. R. Purves. 1983. Iron binding proteins of iron-absorbing rat intestinal mucosa. J. Clin. Invest. 71:14671476.

48. Hovi, T., D. Mosher, and A. Vaheri. 1977. Cultured human monocytes synthesize and secrete $\alpha_{2}$-macroglobulin. J. Exp. Med. 145:1580-1589.

49. Gatter, K. C., G. Brown, I. S. Trowbridge, R. E. Woolston, and D. Y. Mason. 1983. Transferrin receptors in human tissues: their distribution and possible clinical relevance. J. Clin. Pathol. 36:539-545.

50. André, C., F. André, and M. C. Fargier. 1978. Distribution of IgA1 and IgA2 plasma cells in various normal human tissues and in the jejunum of plasma IgA-deficient patients. Clin. Exp. Immunol. $33: 327-331$.

51. Skvaril, F., and A. Morell. 1974. Distribution of IgA subclasses in sera and bone marrow plasma cells of 21 normal individuals. $A d v$. Exp. Med. Biol. 45:433-435. 